Diny Hidayatullah

\title{
HUBUNGAN LOGIKA, BAHASA, DAN BUDAYA
}

Achmad Diny Hidayatullah

Email : diny@uin-malang.ac.id

\begin{abstract}
As creatures that can think, humans need the means of thinking. The means include language and logic. The intersection between logic, language, and culture exists in humans as the culprit. Humans use their logic to speak, and the language used as a communication tool will create a culture. Culture develops with the help of logic, so it can form 'new language' as the development of existing language. Where there are humans it is certain that language and culture exist. Because of the subjects, as well as objects of language and cultured, are human. The relationship of logic, language, culture is a relationship of mutual influence and has a very close relationship. All three become a whole communication system, binding, and enable the work of a society. It is also an interaction system that enables a society to occur, be nurtured and sustainably. Language as a part of the culture is a factor that allows the formation of culture. Language is the most importantly in a culture. Good language, showing a good society culture. Humans are able to maximize the potential of logic, of course, will be able to speak and cultured good. Language is a reflection of the nation's culture. Language shows the personality of the nation."
\end{abstract}

Keywords: logic, language, culture

\section{PENDAHULUAN}

Allah menciptakan manusia sebagai makhluk yang paling sempurna dan mulia. Hal ini sudah dijelaskan dalam Alquran, seperti pada Q.S At-Tīn: 4 dan Q.S Al Isra: 70

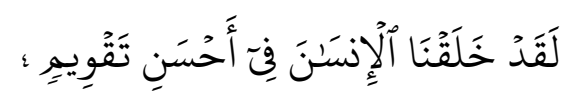

"Sesungguhnya Kami telah menciptakan manusia dalam bentuk yang sebaik-baiknya (Q.S. At-Tīn/95: 4)”.

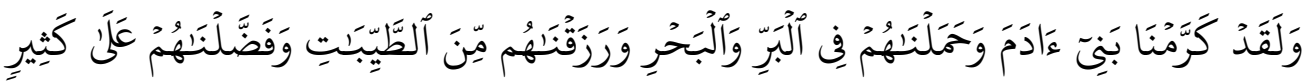

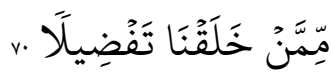


"Dan sesungguhnya telah Kami muliakan anak-anak Adam, Kami angkut mereka di daratan dan di lautan, Kami beri mereka rezeki dari yang baik-baik dan Kami lebihkan mereka dengan kelebihan yang sempurna atas kebanyakan makhluk yang telah Kami ciptakan (Q.S. Al-Isra/17: 70)".

Bahkan, hanya manusia saja yang diberikan kemampuan yang sempurna untuk bisa menggunakan akal pikirannya. Ungkapan yang sangat mashur bahwa الإنسان حيوان ناطق yang artinya bahwa manusia adalah 'hewan' yang bisa berbicara atau menggunakan logikanya. ${ }^{1}$ Atau dalam istilah yang lebih umum, bahwa manusia adalah 'hewan' yang rasional atau bisa berfikir/cerdas (homo sapiens). ${ }^{2}$ Manusia adalah makhluk yang berpikir dan yang dapat berkarya (homo faber). Sebagai makhluk yang dapat berpikir, manusia memerlukan sarana berpikir. Sarana berpikir itu berupa bahasa, logika, matematika, dan statistika. $^{3}$

Sehingga manusia adalah satu-satunya makhluk yang diberikan amanah -juga tanggung jawab- untuk dua tugas mulia dari Allah : sebagai Abdullāh (hamba Allah) dan Khalīfatullāh (wakil Allah di bumi).

Di mana manusia itu ada dapat dipastikan bahwa bahasa dan budaya juga ada. Karena subyek sekaligus obyek dari berbahasa dan berbudaya adalah manusia. Bekal manusia yang dikaruniai akal pikiran, sepatutnya digunakan seoptimal mugkin untuk mengembangkan potensi manusia. Paling tidak, menurut Mudjia Rahardjo, ada tiga kelebihan manusia dibandingkan makhluk yang lain, yaitu : penguasaan bahasa, kemampuan berfikir, dan kesempurnaan bentuk ragawi. ${ }^{4}$

Titik temu antara logika, bahasa, dan budaya secara umum ada pada manusia sebagai pelakunya. Manusia menggunakan logikanya untuk berbahasa, dan bahasa yang digunakan sebagai alat komunikasi akan menciptakan budaya. Budaya berkembang dengan bantuan logika, sehingga bisa membentuk 'bahasa baru' sebagai pengembangan bahasa yang sudah ada. Pola ini merupakan pembahasan utama pada ilmu bahasa

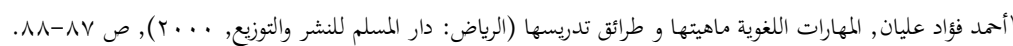

${ }^{2}$ Haidar Bagir, Buku Saku Filsafat Islam (Edisi Revisi), 2nd ed. (Bandung: Mizan, 2006), 67.

${ }^{3}$ Jujun S. Suriasumantri, Filsafat Ilmu: Sebuah Pengantar Populer(Jakarta: Pustaka Sinar Harapan, 1995), 165.

${ }^{4}$ Mudjia Rahardjo, "Bahasa, Pemikiran Dan Peradaban : Telaah Filsafat Pengetahuan Dan Sosiolinguistik.

Pidato Pengukuhan Disampaikan Pada Pengukuhan Jabatan Guru Besar Dalam Bidang Ilmu Sosiolinguistik

Fakultas Humaniora Dan Budaya UIN Malang” (Malang, 2006), 4.
}

71 Volume 2, Nomor 1, Februari 2017 
Diny Hidayatullah

(linguistik) modern yang dirintis oleh para antropolog seperti Franz Boas dan Edward Sapir. ${ }^{5}$

Hubungan antara bahasa dan logika, seringkali menggunakan hipotesis Sapir dan Whorf yang terkenal dengan temuannya terkait cara berfikir seseorang sangat ditentukan oleh bahasa ibunya (native language). Teori ini dikemudian hari dikenal sebagai SapirWhorf Hypothesis.

\section{LOGIKA}

Secara etimologis logika berasal dari bahasa Inggris: logic, Latin: logica, Yunani: logike atau logikos. Yang memiliki arti sesuatu yang dapat dimengerti, akal budi yang berfungsi baik, teratur, sistematis. ${ }^{6}$ Adapun menurut Kamus Besar Bahasa Indonesia, logika berarti pengetahuan tentang kaidah berpikir; ilmu mantik, atau jalan pikiran yang masuk akal. ${ }^{7}$

Adapun secara terminologi, logika adalah teori mengenai syarat-syarat penalaran yang sah. Istilah ini, sejarahnya digunakan pertama kali oleh filsuf Alexander dari Aphrodisias (abad ke-2 M), dimana Alexander memberikan komentar pada tulisan Aristoteles yang disebut organon atau instrumen ilmu yang membahas cikal bakal tentang logika. ${ }^{8}$

Logika adalah studi tentang aturan-aturan mengenai penalaran yang tepat, serta bentuk dan pola pikir yang masuk akal atau sah. Atau juga bisa bermakna sebagai studi dan penerapan aturan-aturan penarikan kesimpulan pada argumen atau pada sistem pemikiran. $^{9}$

Logika adalah salah satu usaha supaya pengetahuan hasil dari proses pemikiran itu mempunyai fondasi kebenaran. Logika bisa artikan sebagai sarana penggunaan hukum yang berupaya menahan akal agar tidak membuat kekeliruan dalam berpikir. ${ }^{1}$

Adapun logis bisa diartikan secara bebas yaitu masuk akal atau dapat diterima oleh akal sehat. Sehingga logika adalah jalan pemikiran ilmiah, yang sesuai dengan akal sehat serta pengetahuan tentang kaidah yang benar.

\footnotetext{
${ }^{5}$ Mudjia Rahardjo, Relung - Relung Bahasa (Yogyakarta: Aditya Media, 2002), 12.

${ }^{6}$ Kinayati Djojosuroto, Filsafat Bahasa (Edisi Revisi) (Yogyakarta: Pustaka Book Publisher, 2007), 153.

${ }^{7}$ Kementerian Pendidikan dan Kebudayaan Republik Indonesia Badan Pengembangan dan Pembinaan Bahasa, "Kamus Besar Bahasa Indonesia V,” 2006, https://kbbi.kemdikbud.go.id (diakses 21 September 2017).

${ }^{8}$ Lorens Bagus, Kamus Filsafat (Jakarta: Gramedia Pustaka Utama, 2000), 761-62.

${ }^{9}$ Djojosuroto, Filsafat Bahasa (Edisi Revisi), 154.

1 Ali Mahdi Khan, Dasar-Dasår Filsafat Islam(Bandung: Penerbit Nuansa., 2004), 79.
}

Volume 2, Nomor 1, Februari 201772 
Sejarah logika pertama kali berkembang pada masa Yunani. Berawal dari pembuktian-pembuktian geometri kaum Pythagorean, dialektika Zeno, atau dialektika Plato. Kemudian dikembangkan secara lebih sistematis oleh Aristoteles, yang berbicara tentang analisis preposisi-preposisi, interelasinya, penggunaannya dalam penalaran, yang mana mencapai pucaknya berupa ajaran silogisme.

Manusia adalah makhluk berfikir. Manusia mencoba mencari kebenaran dengan akalnya. Manusia adalah makhluk belajar. Dalam mengahadapi masalah, kesukaran, dan tantangan, manusia berkeinginan untuk maju, berupaya hidup lebih baik, lebih nyaman, dan kreatif menyelesaikan masalahnya. Manusia mencoba menggunakan akal untuk menyelesaikan masalahnya, trial and error, mencoba-coba, Akhirnya dari pengalaman benar-salah itu manusia memiliki pengalaman.

Pengalaman adalah guru terbaik. Mengkaji ulang pengalaman dengan berfikir reflektif. Sehingga tepat apabila manusia adalah Homo Educandum yaitu manusia adalah makhluk belajar. Menyatukan hasil pembelajarannya, sehingga akal yang digunakan itu menghasilkan banyak hal, seperti ilmu pengetahuan, pernyataan-pernyataan ilmiah berupa preposisi (pernyataan ilmiah tentang segala sesuatu) dan generalisasi (suatu simpulan tentang sesuatu). ${ }^{1}$

Puncak perkembangan logika manusia, adalah pada peradaban Renaissance. Oleh Rane Descartez, puncak itu dinyatakan sebagai eksistensi manusia sebagai homo sapiens, "cogito ergo sum”. Manusia mencoba terus berusaha mencari kebenaran dengan berfikir deduktif, yaitu logika-hipotetiko-verifikatif (berfikir filosofis). Azaz yang sesuai dengan logika ini adalah Azaz Koherensi, yaitu preposisi umum, harus sesuai dengan preposisi turunannya.

Dan pada perkembangannya, Francis Bacon (abad-17), mencoba menawarkan berfikir induktif : data-simpulan, dengan urutan rangkaian : verificatio -> hipotetiko -> logiko. Azaz yang sesuai dengan logika induktif ini, adalah Azaz Korespondensi, yaitu logika/preposisi harus cocok dengan data.

Agama Islam sangat menghargai penggunaan akal pikiran sebagai dasar melaksanakan syariat. Sebagai contoh apa yang dikemukakan Abbas Arfan dalam kajiannya, bahwa logika sangat berpengaruh pada metode istinbāt hukum. Kesimpulan pendapatnya, bahwa kuatnya peran dan pengaruh ilmu filsafat dan logika dalam metode istinbāt hukum Islam terutama dalam ilmu ushul fiqh. Hal ini dikarenakan sangat erat dan

\footnotetext{
1 Tagor Pangaribuan, Paradigina Bahasa (Yogyakarta: Graha Ilmu, 2008), 4-5.
} 
Diny Hidayatullah

mendasarnya hubungan antara ushul fiqh dengan ilmu filsafat dan logika, yakni sebuah hubungan metodologis. ${ }^{1}$

Sebagai sebuah contoh sederhana adalah penggunaan qiyās dalam sistem hukum Islam. Sistem berfikir 'illat sangat erat kaitannya dengan sistem logika silogisme Aristoteles. Hal ini sangat mirip dengan istilah qiȳ̄s 'aqlī atau qiyās mantiqī. Misalnya, Imam Shāfi'i menegaskan bahwa mengusap tangan dengan debu dalam tayammum adalah sampai sikut berdasarkan analogi membasuh tangan dalam berwudu, walaupun ayat tayammum tidak menyebut sampai siku :

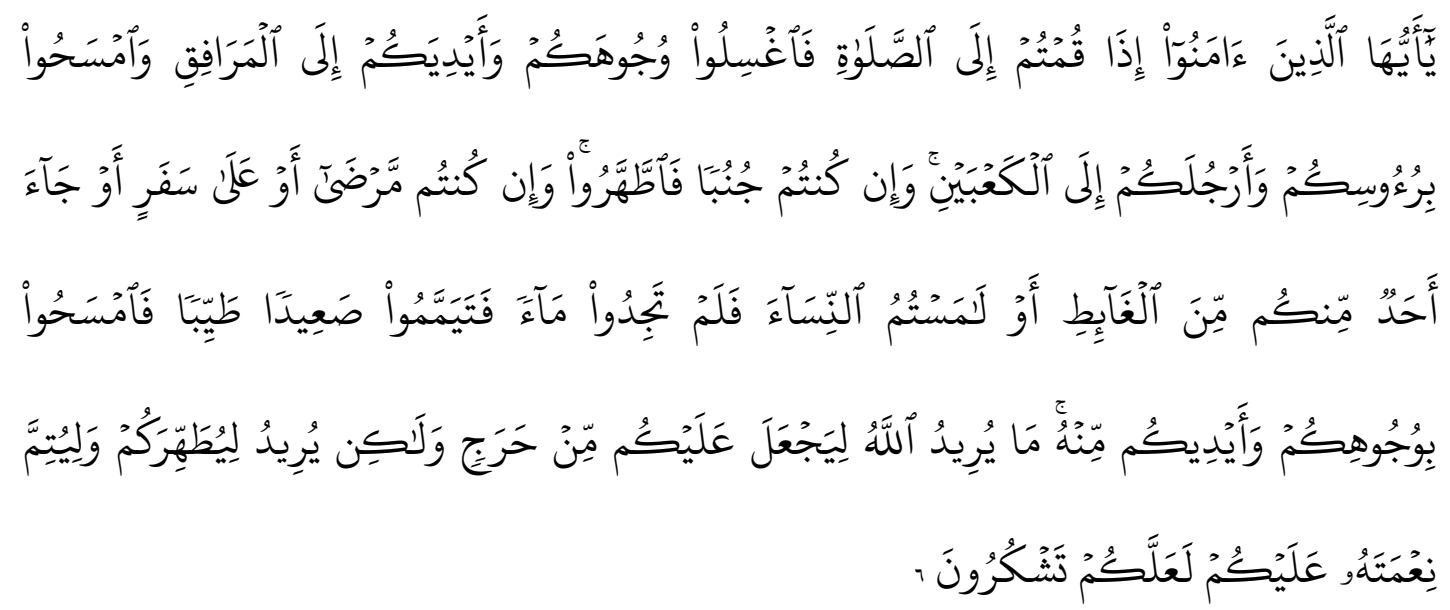

"Hai orang-orang yang beriman, apabila kamu hendak mengerjakan shalat, maka basuhlah mukamu dan tanganmu sampai dengan siku, dan sapulah kepalamu dan (basuh) kakimu sampai dengan kedua mata kaki, dan jika kamu junub maka mandilah, dan jika kamu sakit atau dalam perjalanan atau kembali dari tempat buang air (kakus) atau menyentuh perempuan, lalu kamu tidak memperoleh air, maka bertayammumlah dengan tanah yang baik (bersih); sapulah mukamu dan tanganmu dengan tanah itu. Allah tidak hendak menyulitkan kamu, tetapi Dia hendak membersihkan kamu dan menyempurnakan nikmat-Nya bagimu, supaya kamu bersyukur (Q.S Al-Māidah/5 : 6)".

Apabila demikian, dapat disusun silogisme dengan gambaran sebagai berikut:

Premis mayor : Membasuh tangan dengan air dalam wudu sampai siku

Premis minor : Tayammum adalah pengganti wudu dalam kondisi tertentu

Middle term : Thaharah (bersuci)

Kesimpulan : Mengusap tangan dengan debu dalam tayammum harus juga sampai siku

\footnotetext{
1 Abbas Arfan, "Peran Dan Pengaruh Filsafat Dan Logika Dalam Metode Istinbât Hukum Islam," ULUMUNA 19, no. 1 (June 22, 2015): 93, doi:10.20414/ujis.v19i1.1252.
} 
Sampai disini, dapat disimpulkan bahwa penggunaan salah satu potensi manusia yang utama, yaitu akal, adalah sangat penting. Baik dalam berbahasa, berbudaya, lebihlebih dalam beragama. Sebagai bagian dari kajian filsafat Islam, bahwa penggunaan logika perlu didudukkan dalam porsi yang benar dan wajar. Logika adalah instrumen serta alat untuk dipergunakan pemiliknya agar bisa mewujudkan kehidupan yang baik dan bermanfaat.

Islam sangat menghargai fungsi akal dan logika. Porsi akal mendapat tempat yang istimewa dalam Alquran. Banyak ayat yang mengisyaratkan manusia untuk menggunakan akalnya untuk berfikir. Akan tetapi, akal dan logika bukanlah dewa. Yang mana berfikir logis adalah segalanya. Karena dengan segala kelebihannya, ternyata akal juga memiliki kelemahan. Akal tidak bisa menjangkau hal-hal yang metafisik. Indera-indera manusia seperti mata dan telinga adalah sebagai alat bagi akal untuk berlogika, tapi sangat terbatas pada lima indera saja. Dan keterbatasan akal seringkali tidak bisa menerangkan hal-hal yang bersifat ghaib, seperti : lauh al-mahfudz, malaikat, siksa dan nikmat kubur, iblissyetan, surga-neraka, nasib seseorang, batas umur manusia, serta hal-hal lain yang bisa difahami dengan menggunakan pendekatan iman (hati), melalui wahyu. ${ }^{1}$

\section{BAHASA}

Bahasa adalah salah satu implementasi penggunaan logika oleh manusia. Bahasa membedakan sistem komunikasi antara manusia dengan hewan maupun tumbuhan. Bisa jadi juga, membedakan cara komunikasi antara manusia dengan makhluk Allah yang lain, seperti jin, malaikat, jamadat, dan lain sebagainya. Banyak teori tentang pemerolehan bahasa pada manusia. Yang pasti sejarah Nabi Adam sebagai manusia pertama yang diberi kemampuan Allah swt untuk mengenal asma atau nama-nama benda, sebagaimana firman Allah swt:

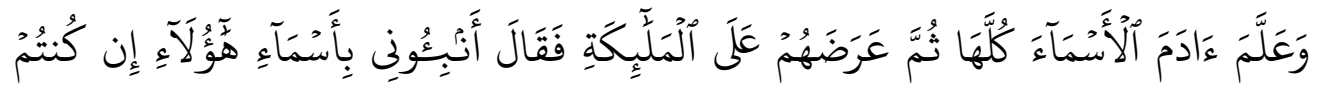

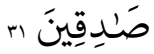

"Dan Dia mengajarkan kepada Adam nama-nama (benda-benda) seluruhnya, kemudian mengemukakannya kepada para Malaikat lalu berfirman: "Sebutkanlah kepada$\mathrm{Ku}$ nama benda-benda itu jika kamu mamang benar orang-orang yang benar! (Q.S ALBaqarâh/2: 31)"

1 M. Zainuddin, Filsafat Eklektika Islam(Yogyakarta: Naila Pustaka, 2016), 75-79. 
Diny Hidayatullah

Berdasarkan Kamus Besar Bahasa Indonesia, bahasa memiliki makna: 1) percakapan (perkataan) yang baik; tingkah laku yang baik; sopan santun; 2) sistem kata atau simbol yang memungkinkan untuk berkomunikasi dengan komputer, terutama untuk memasukkan instruksi-instruksi komputer melalui kata-kata yang mudah dipahami, dan kemudian diterjemahkan ke dalam kode mesin; 3) sistem lambang bunyi yang arbitrer, yang digunakan oleh anggota suatu masyarakat untuk bekerja sama, berinteraksi, dan mengidentifikasikan diri. ${ }^{1}$

Adapun menurut Ibnu Jinni, seorang linguis Muslim, mengatakan bahwa bahasa adalah sistem lambang bunyi yang menggambarkan maksud dari suatu kaum.

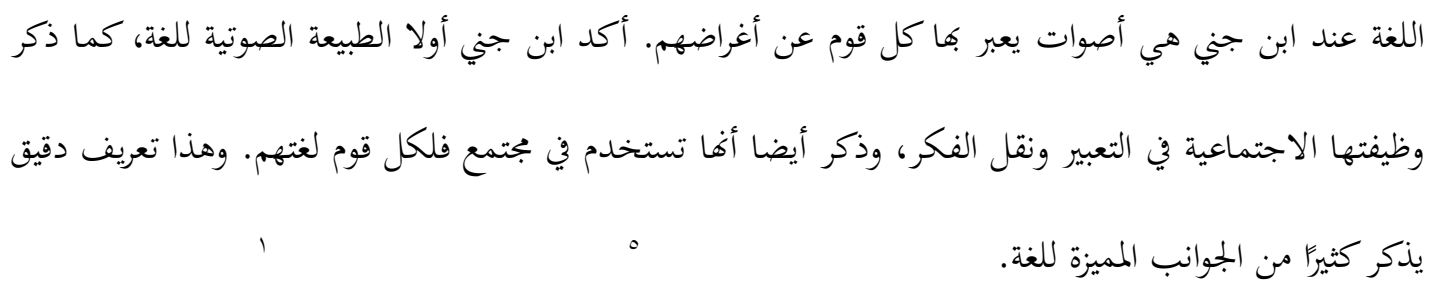

Kajian bahasa, menurut Ibn Jinni tidak dapat dilepaskan dari kajian lafazh dan makna itu sendiri. Lafazh dan makna adalah dua unsur komunikasi yang senantiasa digunakan karena lafazh itu adalah perwujudan dari makna yang ingin disampaikan oleh si pembicara kepada lawan bicaranya. Akan tetapi, setiap lafazh tidak selalu mewakili makna yang sama setiap kali diucapkan. Begitupun suatu makna bisa diwakili oleh lafazh yang berbeda-beda pula sesuai dengan keberagaman si penutur, letak geografis, waktu pengucapan, dialek bahasa, dan sebagainya. Karena itu ketika mempelajari tentang bahasa (suara, lafadz, maupun makna), seorang hendaklah memperhatikan unsur-unsur yang mempengaruhi seperti yang telah diisyaratkan oleh Ibn Jinni dalam bukunya alKhashâ'ish. Bahwa tidak ada dua bahasa atau lebih yang persis sama. ${ }^{1}$

Menurut Dr. Muhammad 'Ali Al-Khouli, bahwa bahasa adalah :

$$
\text { اللغة هي نظام اعتباطي لرموز صوتية تستخدم لتبادل الأفكار والمشاعر بين أعضاء جماعة لغوية متجانسة. }
$$

\footnotetext{
1 Badan Pengembangan dan Pémbinaan Bahasa, "Kamus Besar Bahasa Indonesia V” (diakses 22 September 2017).

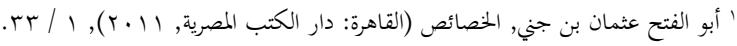

1 Wati Susiawati and Wati, "Láfazh Dan Makna Dalam Perspektif Pemikiran Linguistik Ibn Jinni," Arabiyat : Jurnal Pendidikan Bahasa Arab Dan Kebahasaaraban 2, no. 2 (December 31, 2015): 167-77, doi:10.15408/a.v2i2.2133.

$$
\text { ' محمد علي الخولي ,أساليب تدريس اللغة العربية) عمان: دار الفلاح, . - r), } 10 .
$$
}

Volume 2, Nomor 1, Februari 201776 
Sedangkan bahasa menurut Linguis Barat, seperti Ronald Wardhaugh, adalah seperangkat susunan yang teratur (sistem) lambang-lambang bunyi yang arbiter yang digunakan manusia sebagai alat komunikasi (a system of arbitrary vocal symbols used for human communication). ${ }^{1}$

Fungsi bahasa secara umum adalah sebagai alat komunikasi. Bahkan fungsi inilah tujuan utama manusia berbahasa. ${ }^{1}$ Komunikasi secara seđerhana adalah ada dua orang atau lebih yang saling melakukan percakapan, atau aktifitas lainnya, yang bisa saling memahami makna dan tujuannya. Bisa sama makna. Dalam aspek kebahasaan istilah komunikasi mencakup mengerti makna dan berbicara, mendengar dan merespon suatu tindakan. Fungsi bahasa untuk komunikasi ini, secara umum disimpulkan menurut Roman Jakobson terdapat enam fungsi ${ }^{2}$, yaitu :

1. mempengaruhi dan mengkondisi akal pikiran dan tingkah laku para penutur (Rhetorical Speech).

2. memelihara ikatan sosial dan berlaku pada suasana dan keadaan tertentu (Phatic Speech).

3. psikologis, yaitu dalam menyatakan perasaan prilaku, perbuatan, dan emosi si penutur (Emotive Speech).

4. membicarakan bahasa, ini adalah jenis ujaran yang paling abstrak karena dipakai dalam membicarakan kode komunikasi (Metalingual Speech).

5. mengacu kepada dunia yang sesungguhnya atau denotatif/informatif (Cognitive Speech).

6. mengistimewakan nilai-nilai estetika (Poetic Speech).

Fungsi bahasa yang sangat penting diatas, mengindikasikan bahwa manusia "tidak dapat hidup" tanpa bahasa. Karena dengan bahasa, manusia bisa berkata-kata, melakukan interaksi dan komunikasi, mengungkapkan isi pikiran dan berargumentasi. Karena itu, bahasa adalah sesuatu yang harus ada pada suatu kebudayaan atau masyarakat, sine que non.

Seorang filosof, misalnya, tidak dapat menungkapkan pemikirannya tanpa dibantu dengan bahasa. Pikiran dan hasil perenungan oleh cerdik-cendikia bisa disebarkan

\footnotetext{
1 Ronald Wardhaugh, Introdi̊ction to Linguistics, 2nd ed. (New York: McGraw-Hill, 1977), 3.

1 Asep Ahmad Hidayat, Filsafât Bahasa : Mengungkap Hakikat Bahasa, Makna, Dan Tanda (Bandung: PT. Remaja Rosdakarya, 2006), 26.

2 A. Chaedar Alwasilah, Filsafât Bahasa Dan Pendidikan (Bandung: Remaja Rosdakarya, 2008), 82-83.
} 
Diny Hidayatullah

melalui media bahasa. Alat paling utama dalam berfilsafat adalah bahasa. ${ }^{2}$ Hubungan

filsafat dengan bahasa, itu seperti gula dengan manisnya. Karena bahasa adalah sistem simbol-simbol, sedangkan tugas filsafat adalah memberikan jawaban atau makna dari simbol yang ada tersebut.

\section{BUDAYA}

Secara etimologi budaya sesuai dengan Kamus Besar Bahasa Indonesia adalah 1) sesuatu mengenai kebudayaan yang sudah berkembang (beradab, maju); 2) pikiran; akal budi; 3 ) adat istiadat; 4) sesuatu yang sudah menjadi kebiasaan dan sukar diubah. ${ }^{2}$

Adapun menurut para ahli, seperti Koentjaraningrat kebudayaan dengan memiliki kata dasar budaya yang berasal dari bahasa sansakerta "buddhayah", yaitu bentuk jamak dari buddhi yang berarti "budi" atau "akal”. Jadi Koentjaraningrat mendefinisikan budaya sebagai "daya budi" yang berupa "cipta, karsa, dan rasa". Sedangkan kebudayaan adalah hasil dari cipta, karsa, dan rasa serta bisa diartikan "hal-hal yang barsangkutan dengan akal". ${ }^{2}$ Kebudayaan adalah keseutuhan sistem ide, perbuatan, dan hasil karya manusia dalam kehidupan masyarakat yang dijadikan milik diri manusia.

Budaya merupakan suatu sistem hidup yang menyeluruh. Idealnya bersifat abstrak, kompleks, dan luas. Banyak aspek budaya turut menentukan perilaku komunikatif. Unsur-unsur ini tersebar, dan meliputi banyak kegiatan sosial manusia. ${ }^{2}$ Kesimpulannya, kebudayaan adalah hasil buah budi manusia untuk mencapai kesempurnaan hidup. ${ }^{2}$ Kalau mau dibedakan añtara budaya dan kebudayaan, paling tidak bisa diartikan secara umum bahwa budaya itu digunakan untuk istilah "nilai-nilai" dan "adat kebiasaan", sedangkan kebudayaan adalah suatu gejala kompleks, termasuk adat kebiasaan dan nilai-nilai yang memperlihatkan kesatuan sistemik. ${ }^{2}$

Koentjaraningrat mengemukakan bahwa paling tidak ada tujuh unsur kebudayaan yang bersifat universal. Universal ini menerangkan bahwa unsur-unsur kebudayaan

\footnotetext{
2 Hidayat, Filsafat Bahasa : Mèngungkap Hakikat Bahasa, Makna, Dan Tanda, 31.

2 Badan Pengembangan dan Pêmbinaan Bahasa, "Kamus Besar Bahasa Indonesia V” (diakses 23 September 2017).

2 Koentjaraningrat, Pengantar 3 Ilmu Antropologi (Jakarta: Rineka Cipta, 2009), 146.

2 Deddy Mulyana dan Jalaluddin Rakhmat, Komunikasi Antarbudaya: Panduan Berkomunikasi Dengan Orang-Orang Berbeda Budaya (Bandung: Remaja Rosdakarya, 2006), 25.

2 Sujarwo, Manusia Dan Fenómena Budaya (Yogyakarta: Pustaka Pelajar, 1999), 8-9.

2 E. K. M. Masinambow, “Teóri Kebudayaan Dalam Ilmu Pengetahuan Budaya Dalam Buku Meretas Ranah : Bahasa, Semiotika, Dan Budaya (Buku Persembahan Bagi Prof. Dr. Benny Hoedoro Hoed).” (Yogyakarta: Yayasan Bentang Budaya, 2001), 11-12.
} 
bersifat menyeluruh serta bisa ditemukan dalam kebudayaan yang tersebar di dunia. Ketujuh unsur itu adalah bahasa, sistem religi, sistem teknologi, organisasi sosial, sistem mata pencaharian, sistem ilmu pengetahuan, dan kesenian.

Secara umum, bentuk kebudayaan dibagi menjadi tiga aspek ${ }^{2}$, adalah:

1. Suatu kompleks kegiatan serta tindakan berpola dari manusia dalam masyarakat.

2. Suatu himpunan gagasan, ide, norma, nilai, dan peraturan.

3. Suatu benda-benda hasil ciptaan manusia.

Selain istilah "kebudayaan" (culture) ada juga istilah lain yaitu "peradaban" (civilization). Kebudayaan sebagai bagian dari lingkungan buatan manusia (Man made part of the environment). Yaitu mempunyai berbagai makna dalam kaitannya dengan masyarakat. Istilah ini sering digunakan untuk merujuk pada suatu masyarakat yang kompleks dan multi kelompok, dicirikan oleh praktik dalam sosial, ekonomi, maupun politik. Wujud-wujud peradaban itu sendiri paling tidak ada lima hal yaitu: nilai, moral, norma, etika, dan estetika. Istilah "peradaban" sering juga dipakai untuk menyebut suatu kebudayaan yang mempunyai sistem teknologi, seni bangunan, ilmu pengetahuan, sistem kenegaraan, dan seni rupa dari suatu masyarakat yang maju dan kompleks.

Peradaban, menurut Koentjaraningrat, menekankan kepada dua unsur utama, antara lain:

1. akal (berpikir). Unsur ini lebih sering digunakan pada dunia Barat. Sehingga kemajuan dalam bidang ilmu pengetahuan dan teknologi lebih didahulukan daripada nurani.

2. nurani (perasaan/estetis). Unsur ini lebih banyak diterapkan di dunia Timur, karena lebih mengutamakan perasaan atau hati nurani dibanding dengan rasio atau akal.

\section{ANTARA LOGIKA, BAHASA, DAN BUDAYA}

Dari pembahasan diatas, secara umum bahwa antara berpikir (logika), berbahasa, dan berbudaya adalah tiga aktifitas yang berbeda. Masing-masing memiliki definisi konsep yang mandiri. Akan tetapi memiliki keterkaitan yang sangat erat. Dengan kata yang lebih sederhana, mungkin bisa ditarik garis merahnya, bahwa berbahasa merupakan penyampaian pikiran atau perasaan dari orang-orang yang berbincang tentang masalah

\footnotetext{
${ }^{2}$ Koentjaraningrat, Pengantar ${ }^{7}$ Ilmu Antropologi, 150.
} 
Diny Hidayatullah

yang dihadapi dalam kehidupan budayanya. Jadi, berfikir, berbahasa dan berbudaya adalah tiga hal yang saling berkaitan dan mempengaruhi dalam kehidupan manusia.

Logika adalah dasar. Akal pikiran yang hanya manusia saja yang bisa menggunakannya secara optimal, tentu peluang sekaligus tantangan untuk digunakan sebaik-baiknya. Dengan berfikir logis, manusia bisa menentukan sendiri apa yang hendak dilakukan, dan dengan cara apa.

Begitu juga dalam hal berbahasa dan berbudaya. Akal manusia, tentu saja, ingin menampilkan bahasa dan budayanya sebagai identitas masing-masing komunitas yang adiluhung. Tidak ada komunitas manusia-pun, yang tidak bangga dengaan bahasa dan budayanya. Sehingga manusia terus memikirkan agar bahasa dan budaya nya bisa terus maju, berkembang, dan mendominasi.

Contoh konkrit pendapat diatas adalah kaum Barat, dalam hal ini Amerika. Dimana dengan kemampuan akal pikirannya, mampu menciptakan bahasa-bahasa baru yang mendominasi pada perkembangan ilmu pengetahuan dan teknologi dewasa ini. Seperti kosa kata : flasdisk, internet, e-money, manajemen, likuidasi, dan lain sebagainya. $^{2}$

Secara umum, salah satu unsur budaya yang sangat penting adalah bahasa. Walaupun ada sebuah kajian bahwa bahasa melahirkan budaya, akan tetapi, setelah suatu budaya itu terbentuk, maka akan menghasilkan 'bahasa baru' hasil modifikasi dari budaya yang berkembang.

Bahasa merupakan instrumen bagi seseorang untuk memenuhi kebutuhan sosialnya dalam berinteraksi dengan sesamanya. Bahasa sangat berpengaruh pada kecakapan manusia dalam menciptakan pemahaman tentang fenomena sosial dan membangun tradisi budaya yang diungkapkan secara simbolik. Serta mampu mewariskannya kepada generasi penerusnya. Dengan demikian, bahasa menduduki bagian yang sangat penting dalam suatu kebudayaan.

Keterkaitan antara bahasa dan budaya bisa diambilkan dari contoh kajian antropolog, seperti hasil penelitian Clifort Greetz (1960), The Religion of Java. Yang mana salah satu hasil temuannya adalah tingkatan perkataan dalam bahasa Jawa sebagaimana dalam bahasa Sunda, Madura, maupun Bali merupakan contoh bagaimana

\footnotetext{
2 Rahardjo, Relung-Relung Bahasa, 43-44.
} 
nilai kesopanan budaya secara gamblang terungkap pada kesantunan bahasa. ${ }^{2}$ Sebagai contoh dalam bahasa Jawa, menurut bentuknya, secara garis besar tingkat tutur bahasa Jawa dibagi menjadi tiga tingkatan : basa ngoko (pergaulan) atau basa kasar, basa madya (biasa), basa krama (halus). Dan derivasi dari tingkat tutur itu, bisa mencapai tiga belas tingkatan, seperti krama inggil, ngoko lugu, madyo ngoko, basa kedaton dan lain sebagainya

Melihat contoh diatas, bisa difahami bahwa bahasa merupakan bagian dari kebudayaan. Pada zaman dahulu, pada saat manusia terdiri dari beberapa kumpulan kecil yang tersebar di beberapa tempat di bumi ini, bahasa merupakan unsur pokok yang memuat semua unsur kebudayaan manusia yang lainnya. Pada saat ini, setelah unsurunsur yang lain dari kebudayaan telah merata dan meluas, bahasa cuma merupakan salah satu unsur budaya saja, akan tetapimemiliki fungsi yang sangat penting bagi kehidupan manusia. $^{3}$

Ada beberapa teori yang menjelaskan tentang hubungan logika, bahasa dan budaya, diantaranya ${ }^{3}$ :

\section{Teori Wilhelm Von Humboldt}

Dalam teorinya Humboldt menegaskan terdapat keterkaitan pemikiran manusia pada bahasa. Artinya bahasa masyarakat menentukan pandangan hidup dan budaya suatu itu sendiri. Anggota masyarakat tidak bisa keluar dari aturan yang telah ditentukan oleh bahasanya. Sehingga apabila ada seorang anggota masyarakat ingin mengubah pandangan hidupnya, maka dia perlu belajar bahasa yang lain terlebih dulu.

Bahasa terdiri dari dua bagian penting. Bagian pertama berupa bunyi-bunyi yang dibentuk oleh lautform, dan bagian lainnya berupa pikiran-pikiran yang dibentuk oleh ideenform atau innereform. Bahasa merupakan sintesa dari bunyi dan pikiran, sehingga yang dinamakan bunyi bahasa adalah bentuk-luar, sedangkan pikiran adalah bentukdalam. Bentuk luar bahasa itulah yang bisa kita pancaindera (dengar), sedangkan bentukdalam bahasa berada di dalam otak (akal pikiran). Dengan kata lain bahwa stuktur suatu bahasa menyatakan kehidupan dalam (pikiran atau otak) penutur bahasa itu.

\section{Teori Sapir-Whorf}

\footnotetext{
2 Alip dan Suharso Poedjosoeđarmo, S., Th. Kundjana, G. Soepomo, Tingkat Tutur Bahasa Jawa (Javanese Speech Levels)(Jakarta: Pusat Pembinaan dan Pengembangan Bahasa, Departemen Pendidikan dan Kebudayaan, 1979), 8.

3 Nandang Sarip Hidayat, "Hưbungan Berbahasa, Berpikir, Dan Berbudaya," Sosial Budaya 11, no. 2 (January 5, 2015): 190-205, doi:10.24014/SB.V11I2.834.

3 Abdul Chaer, Psikolinguistik: Kajian Teoretik(Jakarta: Rineka Cipta, 2003), 51.
} 
Diny Hidayatullah

Edward Sapir, seorang linguis Amerika memiliki pendapat yang hampir mirip dengan dengan Humboldt. Sapir menegaskan bahwa manusia hidup di dunia ini di bawah "belas kasih" bahasanya yang telah menjadi media pengantar dalam kehidupan masyarakat, istilahnya bahasa ibunya "native language". Faktanya bahwa kehidupan suatu masyarakat sebagian "didirikan" di atas karakter bahasa itu. Sehingga tidak ada dua bahasa yang benar-benar sama yang bisa mewakili satu kelompok masyarakat yang sama.

Bahasa satu masyarakat telah membuat satu dunia tersendiri untuk penutur bahasa itu. Jadi, sebanyak masyarakat yang hidup di dunia ini, sama dengan banyaknya jumlah bahasa yang terdapat di dunia. Sapir menegaskan bahwa apa yang kita lihat, kita dengar, kita perbuat, dan kita alami saat ini adalah disebabkan oleh "sifat-sifat" bahasa yang ada terlebih dahulu (bahasa ibu). Sehingga persepsi kita terhadap realitas dipengaruhi oleh bahasa pertama yang kita miliki. ${ }^{3}$

Benjamin Lee Whorf, murid Sapir, menolak pandangan lama mengenai hubungan bahasa dan berpikir, yaitu antara bahasa dan berpikir merupakan dua hal yang berdiri sendiri. Menurutnya, sistem tata bahasa suatu bahasa bukan hanya merupakan alat untuk menyuarakan ide-ide, tetapi juga merupakan pembentuk ide-ide itu sendiri. Bahasa adalah program aktivitas mental seseorang, penentu struktur mental seseorang. Dalam ungkapan yang lain, tata bahasalah yang menentukan jalan pikiran seseorang.

Whorf mengajukan satu hipotesis yang lazim disebut hipotesis Whorf (atau juga hipotesis Sapir-Whorf) mengenai Relativitas Bahasa. Bahasa-bahasa yang berbeda menciptakan alam ini dengan cara yang berbeda, sehingga sistem-sistem dan ide tergantung kepada bahasa yang beragam itu. Aturan bahasa bukan merupakan alat mengeluarkan ide, tetapi pembentuk ide-ide itu sendiri. Tata bahasalah yang akan menentukan jalan pikiran seseorang. Hal ini dapat dikatakan bahwa pandangan hidup bangsa-bangsa di Asia Tenggara seperti di Malaysia, Singapura, Indonesia, Thailand, dan Brunai adalah mirip karena bahasa-bahasanya memiliki struktur yang tidak jauh beda. Sedangkan pandangan hidup bangsa-bangsa lain seperti Amerika, Perancis, Eropa, Jepang, Afrika, China, Arab, Brazil adalah berlainan karena struktur bahasanya berlainan.

Salah satu contoh kecil tentang relativitas bahasa, seperti seorang sekretaris yang berkata kepada direktur, "Suratnya sudah Anda tanda-tangani?” dalam budaya Indonesia terkesan kurang sopan. Karena penggunaan Anda sebagai kata ganti orang kedua dalam

\footnotetext{
3 A. Effendi Kadarisman, Men'2urai Bahasa, Menyibak Budaya : Bunga Rampai Linguistik, Puitika, Dan Pengajaran Bahasa (Malang: UIN-Maliki Press, 2009), 18.
}

Volume 2, Nomor 1, Februari 201782 
Bahasa Indonesia kurang memiliki kesantunan bahasa, seharusnya yang lebih sopan seperti, “Apakah suratnya sudah Bapak tanda-tangani?”. Sebaliknya dalam konteks yang sama, dalam budaya barat, misalnya Amerika, ungkapan "Have you signed the letter?" adalah pertanyaan yang santun dalam bahasa Inggris. ${ }^{3}$

\section{Teori Jean Piaget}

Jean Piaget, seorang sarjana Perancis,memiliki pandangan yang berbeda dengan hipotesis Sapir-Whorf. Menurutnya, justru pikiranlah yang membentuk bahasa. Tanpa pikiran bahasa tidak akan pernah ada. Piaget berpendapat untuk menetapkan apakah bahasa terkait dengan pikiran, terdapat dua macam cara, yaitu pikiran terarah (directed) atau pikiran cerdas (intelegent) dan pikiran tak terarah (autistic). ${ }^{3}$

Teori yang dicetuskan Piaget bernama teori pertumbuhan kognisi, yaitu anak-anak mempelajari segala sesuatu mengenai dunia berawal dari tindakan dan aktivitas dari perilaku dan reaksi atas lingkungannya baru kemudian melalui bahasa. Tidak tanduk anak-anak itu merupakan manipulasi dunia pada satu tempat dan waktu tertentu. Bahasa adalah salah satu alat yang memberikan kepada anak-anak itu suatu kemampuan untuk berajak lebih jauh dari tempat dan waktu tertentu itu.

Mengenai hubungan bahasa dengan kegiatan-kegiatan pikiran, menurut Piaget terdapat dua hal utama ${ }^{3}$ :

a. Sumber berpikir secara intelek ini tidak terdapat dalam bahasa, tetapi dalam periode sensomotorik, yakni sistem skema yang dikembangkan secara penuh.

b. Pembentukan pikiran yang tepat terjadi pada waktu yang bersamaan dengan pemerolehan bahasa. Awal terjadinya fungsi lambang ini ditandai oleh bermacammacam perilaku yang terjadi secara serentak.

Piaget juga menegaskan bahwa kegiatan berfikir sebenarnya adalah perilaku yang telah dinuranikan dan dalam aktivitas-aktivitas sensomotor termasuk juga perilaku bahasa.

\section{Teori L.S. Vygotsky}

Vygotsky, seorang sarjana Rusia, memiliki pendapat terkait tahap perkembangan bahasa sebelum adanya pikiran. Dan terdapat satu tahap perkembangan pikiran sebelum

\footnotetext{
3 A. Effendi Kadarisman, Men'3urai Bahasa, Menyibak Budaya : Bunga Rampai Linguistik, Puitika, Dan Pengajaran Bahasa (Malang: UIN-Maliki Press, 2009), 35-36.

3 Soenjono Dardjowidjojo, Psikolinguistik Pengantar Pemahaman Bahasa Manusia (Jakarta: Unika Atma Jaya, 2003), 283.

3 Chaer, Psikolinguistik: Kajian Teoretik, 55.
} 
Diny Hidayatullah

adanya bahasa. Kemudian, kedua garis perkembangan ini saling bersua, dan terjadilah secara serentak- pikiran berbahasa dan bahasa berpikir.

Dalam ungkapan yang lain, bahasa dan pikiran pada tahap permulaan berkembang dengan cara terpisah dan tidak saling mempengaruhi. Seperti itulah anak-anak berpikir dengan memakai bahasa dan berbahasa dengan pikirannya.

Menurutnya, pikiran berbahasa atau verbal thought berkembang melalui beberapa jenjang. Pada mulanya anak-anak harus menyampaikan kata-kata untuk dipahami. Kemudian meningkat ke arah kemampuan mengerti atau berpikir tanpa mengucapkan kata-kata itu. Pada akhirnya ia bisa memisahkan kata-kata yang berarti dan yang tidak memiliki arti.

Antara pikiran dan bahasa memiliki hubungan dalam berproses. Yaitu suatu gerak yang terus menerus dari pikiran ke kata dan dari kata (bahasa) ke pikiran. Dalam memahami gerak pikiran ini kita perlu mengkaji dua bagian ucapan yaitu ucapan dalam, yang memiliki arti (sudut pandang semantik), dan ucapan luar yang berupa bunyi (aspek fonetik).

Menurut Vygotsky, pikiran dan bahasa tidak dipotong dari satu pola. Struktur ucapan tidak hanya mencerminkan pikiran, tetapi juga mengubahnya setelah pikiran beralih menjadi ucapan. Karena itulah bahasa tidak dapat dipakai oleh pikiran seperti memakai kemaja yang sudah siap. Pikiran tidak hanya memilih ekspresinya dalam mengucapkan bahasa atau kata, tetapi juga mendapatkan realitas dan wujudnya dalam ucapan itu.

\section{Teori Noam Chomsky}

Noam Chomsky mengajukan teori klasik mengenai hubungan bahasa dan pemikiran yang disebut Hipotesis Nurani. Pada mulanya, teori ini tidak secara langsung membincang antara bahasa dengan berpikir, tetapi kita dapat menarik kesimpulan terkait hal tersebut, karena Chomsky menegaskan bahwa pengkajian bahasa membukakan sudut pandang yang baik dalam pengkajian proses mental dan berpikir manusia.

Hipotesis ini menegaskan bahwa struktur bahasa ada dalam nurani. Artinya, rumus-rumus bahasa itu dibawa sejak lahir. Pada waktu seorang anak mulai mempelajari bahasa ibunya, dia telah dilengkapi sejak lahir dengan satu peralatan konsep dengan struktur bahasa dalam yang bersifat umum dan universal.

Teori Von Humboldt yang kurang jelas, bisa diperjelas dengan teori Chomsky yang sesuai dengan pandangan rasionalis. Bahasa-bahasa yang ada di dunia adalah sama karena berdasarkan satu sistem yang universal. Kesamaan ini hanyalah pada tingkat 
dalamnya saja atau diistilahkan struktur-dalam (deep structure). Sedangkan pada tingkat luar atau struktur-luar (surface structure) bahasa-bahasa itu berbeda. Struktur-dalam setiap bahasa bersifat otonom; dan dalam bidang ini, tidak ada hubungannya dengan sistem koginisi (pemikiran) pada umumnya, termasuk kecerdasan.

Menurut Chomsky, language is a mirror of the mind. Bahasa merupakan cerminan pikiran. Teori ini secara umum dipahami tentang "universalitas bahasa", sehingga memicu istilah "Gramatika Semesta" atau "Universal Grammar". Linguistik yang bebas konteks. Pendekatannya bersifat mentalistik-formal. Adapun tujuannya yaitu mencari dan merumuskan kaidah-kaidah universal. Sedangkan pendapat linguistik yang lain, bahwa language is a mirror of the society or the culture. Bahasa sangat bergantung aspek sosial dan kultural. ${ }^{3}$

6

\section{Teori Eric Lenneberg}

Lenneberg berpendapat bahwa ditemukan banyak bukti yang menunjukan bahwa manusia menerima warisan biologi asli berupa kemampuan berkomunikasi dengan menggunakan bahasa yang khusus untuk manusia, dan yang tidak ada hubungannya dengan kecerdasan dan pemikiran.

Bukti bahwa manusia telah dipersiapkan secara biologis untuk berbahasa menurut Lenneberg adalah sebagai berikut:

a. Kemampuan berbahasa sangat erat hubungannya dengan bagian-bagian anatomi dan fonologi manusia. Bisa dibuktikan dengan pendekatan ilmu kedokteran modern, tentang fungsi otak yang berpengaruh pada kemampuan berbahasa seseorang.

b. Jadwal perkembangan bahasa yang sama berlaku bagi semua anak-anak normal.

c. Perkembangan bahasa tidak dapat dihambat meskipun pada anak-anak yang mempunyai cacat tertentu. Namun, bahasa anak-anak ini tetap berkembang dengan hanya sedikit kelambatan.

d. Bahasa tidak dapat diajarkan pada mahkluk lain.

e. Setiap bahasa didasarkan pada prinsip-prinsip semantik, sintaksis dan fonologi yang universal.

\footnotetext{
3 Kadarisman, Mengurai Bahasa, Menyibak Budaya : Bunga Rampai Linguistik, Puitika, Dan Pengajaran Bahasa, 17-18.
} 
Diny Hidayatullah

Lenneberg telah menyimpulkan banyak bukti yang menyatakan bahwa upaya manusia untuk berbahasa didasari oleh biologi yang khusus untuk manusia dan bersumber pada genetik tersendiri secara asal.

\section{Teori Bruner}

Bruner memiliki teori yang disebutnya dengan Teori Instrumentalisme. Bahasa merupakan instrumen pada seseorang untuk mengembangkan dan menyempurnakan suatu pemikiran. Bahasa mampu membantu pikiran manusia supaya bisa berpikir lebih sistematis. Berpikir dan berbahasa berkembang dari sumber yang sama. Sehingga keduanya mempunyai bentuk yang sangat serupa dan saling membantu (melengkapi).

Implikasi teori Bruner dalam bidang pendidikan sangatlah besar. Bahasa sebagai instrumen berpikir harus berhubungan langsung dengan perilaku atau aktivitas, dan dengan struktur perilaku ini pada awalnya. Lalu, pada lanjutannya bahasa harus berkembang ke arah suatu bentuk yang gamblang dan ketidak ketergantungan pada konteks.

Syarat utama dalam berbahasa adanya dua kecakapan yang melibatkan kecakapan bahasa, yaitu linguistik dan komunikasi. Dan teori Bruner ini juga mennambahkan adanya kecakapan analisis yang dimiliki oleh setiap manusia yang berbahasa. Kecakapan inilah yang memungkinkan tercapainya peringkat abstrak yang berbeda-beda. Kecakapan ini dapat berkembang menjadi lebih baik dengan pendidikan, yaitu melalui penggunaan bahasa yang formal. Karena kemampuan analisis ini hanya bisa berkembang setelah seseorang memiliki kecakapan komunikasi yang baik. ${ }^{3}$

\section{KESIMPULAN}

Akal dan logika adalah instrumen yang diberikan Allah swt untuk manusia agar bisa digunakan untuk menjalankan tugasnya dimuka bumi ini. Dalam rangka menjalankan tugas itu, manusia dibekali dengan bahasa. Dalam berbahasa, manusia berkembang menciptakan budaya. Dan budaya yang ada, menciptakan bahasa baru sebagai perkembangan bahasa sebelumnya. Bahasa merupakan bagian yang utuh dari perkembangan budaya manusia. Aktivitas-aktivitas yang dilakukan oleh manusia dalam kehidupannya pasti memuat unsur bahasa.

\footnotetext{
3 Chaer, Psikolinguistik: Kajiann Teoretik, 60.
} 
Bahasa adalah bagian dari budaya, begitu menurut Koentjaraningrat. Para ilmuwan lain mempunyai pendapat yang tidak sama tentang hubungan antara budaya dan bahasa. Akan tetapi, secara umum ada dua pendapat tentang hubungan ini ${ }^{38}$, yakni:

1. Hubungan Subordinatif. Bahasa adalah bagian dari budaya. Bahwa budaya suatu bangsa tidaklah mungkin dapat dipelajari tanpa mengkaji terlebih dahulu bahasa bangsa itu sendiri. Karena bahasa suatu bangsa adalah bagian dari kebudayaan bangsa itu. Dan juga pengkajian bahasa suatu penduduk tidak mungkin dipisahkan dari kebudayaan penduduk itu, karena semantik (arti) yang merupakan salah satu unsur dalam kajian bahasa mencakup juga kebudayaan dari suatu penutur bahasa. Hubungan ini bisa digambarkan seperti diagram berikut :

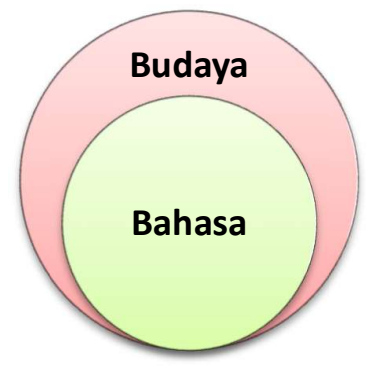

2. Hubungan Koordinatif. Terdapat dua hal yang perlu dicermati, yaitu:

Pertama, pendapat Silzer, dimana hubungan budaya dan bahasa itu seperti kembar siam, dua buah fenomena yang terkait erat atau seperti dua sisi mata uang. Di satu sisi adalah sistem berbahasa dan disisi yang lain adalah sistem berbudaya.

Kedua, berdasarkan hipotesis Edward Sapir dan Benjamin Lee Whorf, yang lazim disebut Relativitas Bahasa. Dimana bahasa bukan hanya menentukan corak berbudaya, tetapi juga bisa memastikan jalan pikiran suatu masyarakat yang berbeda. Jadi, adanya perbedaan-perbedaan budaya dan pikiran manusia itu, bersumber dari berbedanya bahasa suatua masyarakat. Dalam ungkapan yang lain, tanpa bahasa manusia tidak akan mempunyai pikiran sama sekali. Sehingga apabila bahasa mempengaruhi budaya dan jalan berpikir manusia, maka tandatanda yang ada dalam suatu bahasa akan tampak dalam sikap dan budaya penuturnya.

Hubungan ini bisa digambarkan seperti diagram berikut :

${ }^{38}$ Leoni Agustina Abdul Chaier, Sosiolinguistik: Perkenalan Awal(Jakarta: PT. Rineka Cipta, 2000), 155-56. 
Diny Hidayatullah

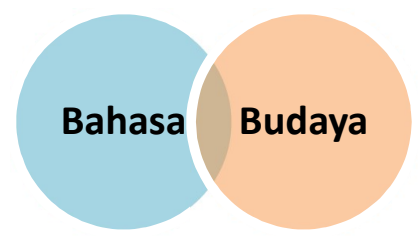

Logika, bahasa, budaya dalam konteks filsafat ilmu bahasa adalah memiliki keterkaitan yang sangat erat. Ketiganya menjadi satu sistem komunikasi yang utuh, mengikat, dan memungkinkan bekerjanya suatu masyarakat. Juga merupakan suatu sistem interaksi yang memungkinkan suatu masyarakat terjadi, terpelihara, dan lestari. Akal adalah kunci, faktor utama berbahasa dan berbudaya. Bahasa sebagai bagian dari budaya adalah faktor yang memungkinkan terbentuknya kebudayaan. Bahasa merupakan sine qua non (yang mesti ada) dan yang paling penting pada suatu budaya.

Bahasa yang baik, menunjukkan suatu budaya masyarakat yang baik. Sebaliknya, budaya yang maju, biasanya dibuktikan dengan terebarnya bahasa budaya itu ke masyarakat yang lain. Manusia yang mampu memaksimalkan potensi logikanya, tentu akan bisa berbahasa dan berbudaya yang baik. Bahasa adalah cermin budaya bangsa. Bahasa menunjukkan kepribadian bangsa. 


\section{DAFTAR PUSTAKA}

Abdul Chaier, Leoni Agustina. Sosiolinguistik: Perkenalan Awal. Jakarta: PT. Rineka Cipta, 2000.

Alwasilah, A. Chaedar. Filsafat Bahasa Dan Pendidikan. Bandung: Remaja Rosdakarya, 2008.

Arfan, Abbas. "Peran Dan Pengaruh Filsafat Dan Logika Dalam Metode Istinbât Hukum Islam.” ULUMUNA 19, no. 1 (June 22, 2015): 93. doi:10.20414/ujis.v19i1.1252.

Badan Pengembangan dan Pembinaan Bahasa, Kementerian Pendidikan dan Kebudayaan Republik Indonesia. "Kamus Besar Bahasa Indonesia V," 2006. https://kbbi.kemdikbud.go.id.

Bagir, Haidar. Buku Saku Filsafat Islam (Edisi Revisi). 2nd ed. Bandung: Mizan, 2006.

Bagus, Lorens. Kamus Filsafat. Jakarta: Gramedia Pustaka Utama, 2000.

Chaer, Abdul. Psikolinguistik: Kajian Teoretik. Jakarta: Rineka Cipta, 2003.

Dardjowidjojo, Soenjono. Psikolinguistik Pengantar Pemahaman Bahasa Manusia. Jakarta: Unika Atma Jaya, 2003.

Djojosuroto, Kinayati. Filsafat Bahasa (Edisi Revisi). Yogyakarta: Pustaka Book Publisher, 2007.

Hidayat, Asep Ahmad. Filsafat Bahasa: Mengungkap Hakikat Bahasa, Makna, Dan Tanda. Bandung: PT. Remaja Rosdakarya, 2006.

Hidayat, Nandang Sarip. "Hubungan Berbahasa, Berpikir, Dan Berbudaya." Sosial Budaya 11, no. 2 (January 5, 2015): 190-205. doi:10.24014/SB.V11I2.834.

Kadarisman, A. Effendi. Mengurai Bahasa, Menyibak Budaya: Bunga Rampai Linguistik, Puitika, Dan Pengajaran Bahasa. Malang: UIN-Maliki Press, 2009.

Khan, Ali Mahdi. Dasar-Dasar Filsafat Islam. Bandung: Penerbit Nuansa., 2004.

Koentjaraningrat. Pengantar Ilmu Antropologi. Jakarta: Rineka Cipta, 2009.

Masinambow, E. K. M. "Teori Kebudayaan Dalam Ilmu Pengetahuan Budaya Dalam Buku Meretas Ranah: Bahasa, Semiotika, Dan Budaya (Buku Persembahan Bagi Prof. Dr. Benny Hoedoro Hoed).," xix, 508 index. Yogyakarta: Yayasan Bentang Budaya, 2001.

Pangaribuan, Tagor. Paradigma Bahasa. Yogyakarta: Graha Ilmu, 2008.

Poedjosoedarmo, S., Th. Kundjana, G. Soepomo, Alip dan Suharso. Tingkat Tutur Bahasa Jawa (Javanese Speech Levels). Jakarta: Pusat Pembinaan dan Pengembangan Bahasa, Departemen Pendidikan dan Kebudayaan, 1979.

Rahardjo, Mudjia. "Bahasa, Pemikiran Dan Peradaban : Telaah Filsafat Pengetahuan Dan Sosiolinguistik. Pidato Pengukuhan Disampaikan Pada Pengukuhan Jabatan Guru Besar Dalam Bidang Ilmu Sosiolinguistik Fakultas Humaniora Dan Budaya UIN Malang." Malang, 2006.

- Relung - Relung Bahasa. Yogyakarta: Aditya Media, 2002.

Rakhmat, Deddy Mulyana dan Jalaluddin. Komunikasi Antarbudaya: Panduan Berkomunikasi Dengan Orang-Orang Berbeda Budaya. Bandung: Remaja Rosdakarya, 2006.

89 Volume 2, Nomor 1, Februari 2017 
Diny Hidayatullah

Sujarwo. Manusia Dan Fenomena Budaya. Yogyakarta: Pustaka Pelajar, 1999.

Suriasumantri, Jujun S. Filsafat Ilmu: Sebuah Pengantar Populer. Jakarta: Pustaka Sinar Harapan, 1995.

Susiawati, Wati, and Wati. "Lafazh Dan Makna Dalam Perspektif Pemikiran Linguistik Ibn Jinni." Arabiyat : Jurnal Pendidikan Bahasa Arab Dan Kebahasaaraban 2, no. 2 (December 31, 2015): 167-77. doi:10.15408/a.v2i2.2133.

Wardhaugh, Ronald. Introduction to Linguistics. 2nd ed. New York: McGraw-Hill, 1977.

Zainuddin, M. Filsafat Eklektika Islam. Yogyakarta: Naila Pustaka, 2016.

$$
\begin{aligned}
& \text { الخولي, محمد علي. أماليب تلدريس اللغة العببية. عمان: دار الفلاح, . ... . . } \\
& \text { جني, أبو الفتح عثمان بن. الخصائص. القاهرة: دار الكتب المصرية, II ـ r. } \\
& \text { عليان, أحمد فؤاد. المهارات اللغوية ماهيتها و طرائق تلدريسها ـ الرياض: دار المسلم للنشر والتوزيع, . . . . . }
\end{aligned}
$$

